\title{
Analisis Daya Dukung Lingkungan Wisata Alam Coban Talun, Kota Batu
}

\author{
${ }^{1}$ Akhmad Faruq Hamdani, ${ }^{2}$ Nila Restu Wardani \\ ${ }^{1,2}$ Program Studi Pendidikan Geografi, Universitas Kanjuruhan Malang \\ email: '1a.faruqhamdani@unikama.ac.id; ${ }^{2}$ nilarestu@unikama.ac.id.
}

\begin{abstract}
Coban Talun is a natural tourism object in Kota Batu (Batu city) and located in forest area managed by Perhutani. The average of the visitor in the last year (2016-2017) amounts to 6.300 visitors per month. Based on the increase of visitor, there's need analysis concerning to environmental carrying capacity of Coban Talun Tourism. The method used is quantitative with calculation Cifuentes formula (1992) that modified in order to find out the physical carrying capacity $(P C C)$, real carrying capacity (RCC), management capacity $(M C)$, and effective carrying capacity (ECC). The data collection was done by the field survey, questionnaire, and interview. The analysis of environmental carrying capacity based on the calculated result shows the PCC score or the maximum visitor accepted in the 40 Ha tourism area is 10.770 visitor/day, the management capacity score (MC) is 0,75 , real carrying capacity is 630 visitor/day, and effective carrying capacity score (ECC) is 460 visitor/day. The analysis of environmental carrying capacity can be a consideration for the manager of Coban Talun in maximizing the number of tourist visit amounted to $119 \%$ or 250 visitors from the average number of a visitor at this time amounted to 210 visitors, therefore the score of ECC that is 460 visitor/day can be achieved.
\end{abstract}

Keywords: Environmental Carrying Capacity, Nature Tourism, Coban Talun.

\begin{abstract}
Abstrak. Coban Talun merupakan objek wisata alam di Kota Batu dan terletak pada kawasan hutan yang dikelola Perhutani. Rata-rata jumlah kunjungan wisatawan setahun terakhir (2016-2017) ini mencapai 6.300 wisatawan tiap bulan. Adanya kenaikan jumlah wisatawan, maka diperlukan analisis mengenai daya dukung lingkungan objek wisata Coban Talun. Metode yang digunakan adalah metode penelitian kuantitatif dengan perhitungan menggunakan rumus Cifuentes (1992) yang dimodifikasi untuk mengetahui daya dukung fisik (PCC), daya dukung riil (RCC), kapasitas manajemen (MC), dan daya dukung efektif (ECC). Pengumpulan data dilakukan dengan survei lapangan, kuesioner, dan wawancara. Analisis daya dukung lingkungan berdasarkan hasil perhitungan menunjukkan nilai PCC atau jumlah maksimum wisatawan yang dapat diterima di areal wisata dengan luas 40 Ha sebesar 10.770 wisatawan/hari dengan nilai kapasitas manajemen (MC) sebesar 0,75, daya dukung riil sebesar 630 wisatawan/hari, dan nilai daya dukung efektif (ECC) sebesar 460 wisatawan/hari. Analisis daya dukung lingkungan ini dapat menjadi pertimbangan pengelola objek wisata Coban Talun dalam memaksimalkan jumlah kunjungan wisatawan sebesar $119 \%$ atau 250 wisatawan dari rata-rata jumlah kunjungan saat ini sebesar 210 wisatawan, sehingga nilai ECC sebesar 460 wisatawan/hari terpenuhi.
\end{abstract}

Kata Kunci: Daya Dukung Lingkungan, Wisata Alam, Coban Talun.

\section{Pendahuluan}

Kota Batu merupakan salah satu kota di Jawa Timur dengan bentang alam dan budaya yang sangat potensial dikembangkan menjadi kota pariwisata. Sejak tahun 2006 Kota Batu mendapat 
sebutan sebagai Kota Wisata Batu karena bentang alam dan budayanya yang sangat banyak dikembangkan sebagai tempat wisata. Kota Batu secara astronomis terletak di $112^{\circ} 17^{\prime} 10,90^{\prime \prime}-$ $122^{\circ} 57^{\prime} 11^{\prime \prime}$ BT dan $7^{\circ} 44^{\prime} 55,11^{\prime \prime}-8^{\circ} 26^{\prime} 35,45^{\prime \prime}$ LS. Secara geografis berbatasan dengan Kabupaten Mojokerto dan Kabupaten Pasuruan di bagian utara, Kabupaten Malang di bagian selatan, bagian barat, dan timur. Secara administratif Kota Batu baru terbentuk sejak tahun 2011 dengan memisahkan kegiatan administratif dari Kabupaten Malang.

Beberapa objek wisata yang berupa bentang alam di Kota Batu adalah Air Panas

Canggar, Kaliwatu Rafting, Pemandian Alam Air Panas Songgoriti, dan Coban Talun, sedangkan objek wisata berupa bentang budaya adalah Jatim Park, Museum Angkut, Candi Songgoriti, Vihara Dammadhipa Arama, Kampung Wisata Kungkuk, Desa Wisata Sumberejo, dan Alun-Alun Kota Batu. Kota Batu dengan potensi fisik dan potensi budayanya banyak menarik wisatawan untuk datang berkunjung.

Berdasarkan data dari Badan Pusat Statistik jumlah wisatawan yang datang ke Kota Batu mengalami kenaikan sejak tahun 2012 hingga 2016. Tercatat jumlah wisatawan yang datang pada tahun 2012 sebanyak 1.603 .441 wisatawan, tahun 2013 sebanyak 1.881 .446 wisatawan, tahun 2014 sebanyak 2.089.022 wisatawan, dan tahun 2015 sebanyak 2.249.201 wisatawan (BPS, 2016). Jika dirata-rata maka kunjungan wisatawan pada tahun 2015 perbulannya adalah 187.433 wisatawan yang berkunjung ke Kota Batu.

Tingginya angka kunjungan wisatawan ke Kota Batu perlu mendapat perhatian khusus dalam segi lingkungannya. Karena semakin besar jumlah wisatawan yang datang maka semakin besar pula tekanan penduduk terhadap lahan wisata di Kota Batu. Pada waktu tertentu ketika kondisi lingkungan sudah melebihi daya dukungnya maka akan terjadi ketidakseimbangan kondisi lingkungan yang akan menyebabkan terjadinya kerusakan.

Coban Talun sebagai salah satu destinasi wisata di Kota Batu berada di Dusun Wonorejo Desa Tulungrejo, Kecamatan Bumiaji. Coban Talun sebagai objek wisata alam yang mengandalkan air terjun dan pemandangan wisata alam sebagai faktor penarik wisatawan. Berdasarkan data dari Perum Perhutani jumlah kunjungan wisatawan dari tahun 2009-2011 mengalami kenaikan dan pada tahun 2011-2013 mengalami penurunan. Tercatat data jumlah wisatawan tahun 2009 adalah 56 wisatawan, tahun 2010 adalah 397 wisatawan, tahun 2011 adalah 7851 wisatawan, tahun 2012 adalah 6262 wisatawan, dan tahun 2013 adalah 539 wisatawan (Amajida, 2016). Tingginya jumlah wisawatan yang berwisata di Coban Talun patut untuk diperhatikan, terutama berkaitan dengan daya dukung lingkungan wisatanya.

Daya dukung lingkungan merupakan kemampuan lingkungan hidup untuk mendukung kehidupan manusia dan mahkluk hidup lainnya (Soemarwoto, 2008). Dalam konteks pariwisata daya dukung lingkungan merupakan jumlah wisatawan yang dapat diterima oleh suatu lokasi wisata tanpa ada perubahan negatif pada lingkungannya (Holden, 2000). Lingkungan mempunyai kemampuan terbatas dalam mendukung kehidupan manusia. Pada waktu tertentu ketika kondisi lingkungan sudah melebihi daya dukungnya maka akan terjadi ketidakseimbangan kondisi lingkungan yang akan menyebabkan terjadinya kerusakan.

Berdasarkan permasalahan tersebut maka tujuan utama dalam penelitian ini adalah menganalisis data dukung lingkungan wisata Coban Talun Kota Batu. Dengan mengetahui daya dukung lingkungan wisata Coban Talun maka dapat diketahui sejauh mana kondisi lingkungan wisata mampu menampung pengunjung yang datang dengan mempertimbangkan berbagai faktor yang ada. Harapannya kondisi lingkungan wisata Coban Talun masih tetap lestari tidak hanya untuk generasi saat ini tapi juga untuk generasi akan datang.

\section{Metode Penelitian}

Metode penelitian dalam penelitian ini adalah metode penelitian kuantitatif. Metode penelitian kuantitatif digunakan untuk menganalisis daya dukung lingkungan wisata Coban Talun. Lokasi penelitian berada pada Wana Wisata Coban Talun, Dusun Wonorejo Desa Tulungrejo, Kecamatan Bumiaji. Tahapan penelitian yang dilakukan antara lain:

1. Melakukan observasi lapangan objek wisata Coban Talun. 
2. Melakukan pengumpulan data primer dalam bentuk wawancara dan kuesioner kepada pihak pengelola objek wisata Coban Talun dan data sekunder yang dibutuhkan dalam penelitian.

3. Melakukan analisis daya dukung lingkungan wisata melalui analisis Efective Carrying Capacity dari Cifuentes dalam Lucyanti, et al (2013) Rumus penghitunganya adalah:

\section{$E C C=P C C x M C$}

Keterangan:

ECC (Efective Carrying Capacity) = daya dukung efektif yaitu jumlah optimum daya tampung wisatawan berdasarkan pertimbangan pengelola

PCC (Physical Carrying Capacity) $=$ daya dukung fisik yaitu jumlah maksimum wisatawan yang dapat diterima di areal wisata tersebut. Rumus penghitungannya adalah sebagai berikut:

Keterangan:

$$
P C C=A x \frac{1}{B} x R f
$$

$\mathrm{A}=$ luas area berwisata

$\mathrm{B}=$ luas area yang dibutuhkan oleh seorang wisatawan untuk berwisata dengan tetap memperoleh kepuasan.

$\mathrm{Rf}=$ faktor rotasi atau pengulangan kunjungan per hari.

RCC (Real Carrying Capacity) = daya dukung riil yaitu jumlah maksimum pengunjung yang dapat mengunjungi situs lokasi wisata tertentu dengan memperhatikan faktor koreksi fisik . Faktor koreksi fisik yaitu: Cf1 (indeks kelerengan); Cf2 (Indeks Potensi Lanskap); Cf3 (Indeks Curah Hujan); Cf4 (Indeks Erosivitas).

$$
R C C=P C C \times C f_{1} \times C f_{2} x C f_{3} x \ldots C f n
$$

MC (Management Capacity) adalah jumlah petugas pengelola wisata. Rumus penghitungannya adalah sebagai berikut:

Keterangan:

$$
M C=\frac{R n}{R t}
$$

$\mathrm{Rn}=$ jumlah petugas pengelolaan yang ada

$\mathrm{Rt}=$ jumlah petugas pengelolaan yang dibutuhkan

\section{Hasil dan Pembahasan}

\section{Kondisi Geografis Lokasi Penelitian}

Objek wisata Coban Talun menjadi lokasi penelitian yang terletak di Dusun Wonorejo Desa Tulungrejo Kecamatan Bumiaji Kota Batu. Objek wisata Coban Talun pada ketinggian $1.500 \mathrm{~m}$ dpl dengan luas wilayah $40 \mathrm{Ha}$. Rata-rata curah hujan di objek wisata ini 239 $\mathrm{mm} /$ bulan, sedangkan rata-rata hari hujan sebanyak 3 hari atau tercatat sebanyak 14 hari terjadi hujan di setiap bulannya (BPS Kota Batu, 2016). Suhu udara berkisar $15^{\circ}-19^{\circ} \mathrm{C}$ dan suhu maksimal pada musim panas yakni $28^{\circ} \mathrm{C}$.

Objek wisata Coban Talun yang berada di Desa Tulungrejo ini memiliki batas: Desa Sumberbrantas (sebelah utara); Desa Punten (sebelah selatan); Desa Sumbergondo (sebelah timur); sebelah barat yakni kawasan hutan Perhutani dan Taman Hutan Raya (Tahura) Raden Suryo. Desa Tulungrejo terdiri dari lima dusun, yaitu: Dusun Wonorejo; Dusun Junggo; Dusun Kekep; Dusun Gerdu; Dusun Gondang. Jumlah penduduk Desa Tulungrejo yaitu 9.491 jiwa (BPS Kota Batu, 2016). Berdasarkan jumlah penduduk ini, persentase terbagi menjadi $90 \%$ petani dan 10\% lain-lain. Dari 90\% tersebut terbagi menjadi $60 \%$ petani apel dan $30 \%$ petani sayur pada hutan produksi milik Perhutani. 


\section{Daya Dukung Lingkungan Wisata Coban Talun}

Pada awalnya, objek wisata Coban Talun dikenal sebagai tempat perkemahan yang letaknya di kawasan hutan yang dikelola Perhutani. Objek wisata ini mulai ramai dikunjungi pengunjung pada November 2016. Objek wisata yang awalnya dikembangkan sebagai tempat perkemahan, sekarang telah dikembangkan menjadi tempat wisata yang lebih menarik minat pengunjung. Hal ini dikarenakan pada objek wisata ini telah dibangun penginapan dan beberapa wahana permainan sebagai penunjang fasilitas objek wisata.

Perkembangan objek wisata Coban Talun menjadikan objek wisata ini mengalami kenaikan jumlah pengunjung. Salah satu pengelola objek wisata yaitu Roy menyatakan bahwa rata-rata jumlah kunjungan wisatawan setahun terakhir (2016-2017) ini mencapai 6.300 wisatawan tiap bulan. Pembangunan objek wisata mulai dari sarana dan prasarana, wahana permainan, promosi, serta pengadaan even-even besar seperti offroad dan motorcross menjadikan objek wisata Coban Talun dikenal wisatawan domestik baik di dalam dan luar Kota Batu.

Adanya kenaikan jumlah wisatawan, maka diperlukan analisis mengenai daya dukung lingkungan kaitannya dengan daya dukung objek wisata Coban Talun. Analisis daya dukung lingkungan ini diperoleh dari perhitungan jumlah optimum daya tampung wisatawan berdasarkan pertimbangan pengelola. Berikut ini data yang diperoleh dan hasil perhitungannya.

Tabel 1. Data dan Perhitungan PCC

\begin{tabular}{clc}
\hline No & \multicolumn{1}{c}{ Data yang diperoleh } & Jumlah \\
\hline 1 & A=luas area berwisata & $40 \mathrm{Ha}^{2}$ \\
2 & $\begin{array}{l}\text { B= luas area yang dibutuhkan oleh seorang wisatawan untuk berwisata } \\
\text { dengan tetap memperoleh kepuasan }\end{array}$ & $65 \mathrm{~m}^{2}$ \\
3 & Jam buka objek wisata & 11 jam \\
4 & Rata-rata durasi kunjungan wisatawan (35 responden) & $6,5 \mathrm{jam}$ \\
5 & Rf=faktor rotasi atau pengulangan kunjungan per hari & 1,75 jam \\
& (Jam buka objek wisata/ Rata-rata durasi kunjungan wisatawan) & 10.770 wisatawan/hari \\
\hline
\end{tabular}

Tabel 2. Data dan Perhitungan MC

\begin{tabular}{clc}
\hline No & \multicolumn{1}{c}{ Data yang diperoleh } & Jumlah \\
\hline 1 & $\mathrm{Rn}=$ jumlah petugas pengelolaan yang ada & 18 \\
2 & $\mathrm{Rt}=$ jumlah petugas pengelolaan yang dibutuhkan & 24 \\
\hline & $\boldsymbol{M C}=\frac{\boldsymbol{R} \boldsymbol{n}}{\boldsymbol{R} \boldsymbol{t}}$ & 0,75 \\
\hline
\end{tabular}

Tabel 3. Data dan Perhitungan ECC Tanpa Memperhitungkan Faktor Koreksi

\begin{tabular}{clcc}
\hline No & & Data yang diperoleh & Jumlah \\
\hline 1 & PCC & 10.770 \\
2 & MC & 0,75 \\
\hline & $\boldsymbol{E C C}=\boldsymbol{P C} \boldsymbol{C} \boldsymbol{x} \boldsymbol{M C}$ & 8.078 wisatawan/hari \\
\hline
\end{tabular}

Berdasarkan perhitungan pada ketiga tabel di atas, maka jumlah wisatawan secara fisik dapat mengunjungi objek wisata Coban Talun dengan tetap memperoleh kepuasan (PCC) yaitu 10.770 wisatawan/hari. Douglas dalam Fandeli \& Muhammad (2009) menyatakan bahwa luas area yang dibutuhkan seorang wisatawan dengan tetap memperoleh kepuasan (B) untuk jenis aktivitas wisatawan berpiknik yaitu $65 \mathrm{~m}^{2}$. Rata-rata jumlah kunjungan wisatawan yang datang ke objek wisata Coban Talun yaitu 210/hari (Roy, 2017). Jumlah kunjungan ini masih jauh di bawah perhitungan nilai daya dukung fisik yaitu 10.770/hari. Nilai daya dukung fisik ini sangat tinggi karena sangat luasnya objek wisata (A) yaitu mencapai $40 \mathrm{Ha}$ atau $400.000 \mathrm{~m}^{2}$. 
Perhitungan selanjutnya yaitu daya dukung efektif atau Efective Carrying Capacity (ECC). ECC dipengaruhi oleh kapasitas manajemen atau Management Capacity (MC). Kapasitas manajemen ditentukan dari jumlah pengelola yang ada. Pengelolaan objek wisata ini dilakukan oleh pihak Perhutani, Lembaga Masyarakat Desa Hutan (LMDH), perkumpulan warga Dusun Wonorejo yang dikoordinasi oleh Ketua RW, dan dari pihak investor. Dari perhitungan diperoleh nilai ECC yaitu 8.078 wisatawan/hari. Jadi, jumlah wisatawan/hari yang efektif mengunjungi objek wisata seluas $400.000 \mathrm{~m}^{2}$ ini sebesar 8.078 wisatawan.

Tabel 4. Data dan Perhitungan RCC dengan Faktor Koreksi Kondisi Fisik

\begin{tabular}{|c|c|c|}
\hline No & Data yang diperoleh & Jumlah \\
\hline 1 & $\mathrm{Cf}_{1}$ (Indeks Kelerangan) & 0,6 \\
\hline 2 & $\mathrm{Cf}_{2}$ (Indeks Potensi Lanskap) & 0,93 \\
\hline 3 & $\mathrm{Cf}_{3}$ (Indeks Curah Hujan) & 0,17 \\
\hline 4 & $\mathrm{Cf}_{4}$ (Indeks Erosivitas) & 0,6 \\
\hline & $R C C=P C C \times C f_{1} \times C f_{2} \times C f_{3} \times C f 4$ & 613 wisatawan/hari \\
\hline
\end{tabular}

Tabel 5. Data dan Perhitungan ECC Dengan Memperhitungkan Faktor Koreksi Kondisi Fisik

\begin{tabular}{clcc}
\hline No & & Data yang diperoleh & Jumlah \\
\hline 1 & RCC & 613 \\
2 & MC & 0,75 \\
\hline & $\boldsymbol{E C C}=\boldsymbol{R C C} \boldsymbol{x} \boldsymbol{M C}$ & 460 wisatawan/hari \\
\hline
\end{tabular}

Faktor koreksi fisik merupakan faktor pembatas daya dukung lingkungan objek wisata Coban Talun. Keempat faktor koreksi fisik ini akan menentukan nilai RCC. Nilai RCC menunjukkan jumlah maksimum pengunjung yang dapat mengunjungi objek wisata Coban Talun dengan memperhatikan faktor fisik yaitu sebesar 613 wisatawan/hari. Penentuan nilai RCC memperhatikan indeks kelerengan, indeks potensi lanskap, indeks curah hujan, indeks erosivitas. Pertama, indeks kelerengan nilainya adalah 0,6 (agak curam). Indeks kelerangan dihitung melalui nilai rata-rata empat lokasi dalam wisata Coban Talun, yakni 1) camping ground dengan nilai 0,4 (landai), 2) air terjun dengan nilai 1 (sangat curam), 3) area offroad dengan nilai 0,6 (agak curam), 4) hutan produksi dan penangkaran lutung dengan nilai 0,4 (landai).

Kedua, indeks potensi langkap yang nilainya 0,93. Indeks potensi lanskap mempertimbangkan acuan dari Bureau of Land Management (dalam Fandeli dan Muhammad, 2009). Ketiga, indeks curah hujan dengan nilai 0,17 dengan menghitung perbandingan rata-rata hujan kering dengan rata-rata hujan basah selama 25 tahun terakhir. Keempat, indeks erosivitas yang dinilai dari jenis tanah andosol dengan kepekaan tanah sebesar 0,6.

Berdasarkan perhitungan faktor koreksi fisik dan kapasitas manajemen, maka nilai Effective Carrying Capacity (ECC) sebesar 460 wisatawan/hari. Nilai ECC ini menunjukkan bahwa jumlah wisatawan masih bisa dimaksimalkan sebesar $119 \%$ atau 250 wisatawan dari rata-rata jumlah kunjungan saat ini sebesar 210 wisatawan, sehingga nilai ECC sebesar 460 wisatawan/hari terpenuhi. Kapasitas manajemen (MC) sebesar 0,75 yang terdiri dari pengelola objek wisata dinilai mampu melayani jumlah kunjungan wisatawan yang datang saat ini.

Daya dukung lingkungan objek wisata Coban Talun berdasarkan perhitungan daya dukung fisik, daya dukung riil, kapasitas manajemen, dan daya dukung efektif yang ada diharapkan bisa menjadi dasar memaksimalkan jumlah wisatawan yang datang dengan tetap memperhatikan kepuasan dan kenyamanan wisatawan.

Berdasarkan perhitungan ECC objek wisata Coban Talun, maka jumlah kunjungan wisatawan masih bisa ditingkatkan. Jika rata-rata jumlah kunjungan 210/hari, maka kunjungan wisatawan bisa lebih ditingkatkan dengan kapasitas manajemen yang ada. Agar kegiatan kepariwisataan memberikan manfaat positif dalam aspek ekonomi, sosial, budaya, dan lingkungan. Disamping manfaat yang diberikan dari perkembangan dan pertumbuhan kepariwisataan, juga perlu diantisipasi dampak-dampak negatif yang mungkin ditimbulkan bila perlu mengurangi atau bahkan dapat menghilangkannya. 
Kegiatan mengoptimalkan potensi wisata melalui peningkatan daya dukung lingkungan dan kualitas hidup melalui teknologi dan rekayasa diharapkan mampu menaikkan nilai tambah sumber daya alam. Secara alami teknologi dapat merubah fungsi dan kedudukan dalam ekosistem. Awalnya berupa natural environment berubah menjadi man made environment (Muta'ali, 2012). Wisatawan yang berkunjung bisa menikmati keindahan air terjun sebagai wisata bentang alam, maupun man made environment berupa penginapan "apache", spot foto "pagupon" dan "oyot", camping ground, taman bunga, sikuit offroad dan arena motorcross.

\section{Kesimpulan}

Berdasarkan perhitungan daya dukung lingkungan objek wisata Coban Talun, maka diperoleh nilai daya dukung fisik (PCC) atau jumlah maksimum wisatawan yang dapat diterima di areal wisata dengan luas $40 \mathrm{Ha}$ sebesar 10.770 wisatawan/hari dengan nilai kapasitas manajemen (MC) sebesar 0,75, dan nilai daya dukung efektif (ECC) sebesar 8.078 wisatawan/hari dengan mempetimbangkan nilai PCC dan MC, sedangkan berdasarkan perhitungan faktor koreksi fisik dan kapasitas manajemen, maka nilai ECC sebesar 460 wisatawan/hari. Nilai ECC ini menunjukkan bahwa jumlah wisatawan masih bisa dimaksimalkan sebesar $119 \%$. Analisis daya dukung lingkungan ini dapat menjadi pertimbangan pengelola objek wisata Coban Talun dalam mengoptimalkan jumlah kunjungan wisatawan tetapi tetap memperhatikan daya dukung lingkungan.

\section{Daftar pustaka}

2016. Profi Desa Tulungrejo Kecamatan Bumiaji Kota Batu. Pemerintah Desa Tulungrejo. Batu dalam Angka. 2016. Kota Batu: Badan Pusat Statistik.

Amazida, D.L. 2016. Strategi Perum Perhutani KPH Malang Dalam Mengembangkan Objek Wisata Coban Talun Kota Batu. (Online: diakses 10 September 2017, http://jurnalmahasiswa.unesa.ac.id/index.php/publika/article/view/15073/19079).

Fandeli,C. dan Muhammad, N. 2005. Pengembangan Ekowisata Berbasis Konservasi di Taman Nasional. Yogyakarta: Fakultas Kehutanan Universitas Gadjah Mada, Pusat Studi Pariwisata UGM dan Kantor Kementrian Lingkungan Hidup.

Holden, A. 2000. Environment and Tourism. London and New York: Routledge.

Lucyanti, S., et al. 2013. Penilaian Daya Dukung Wisata di Objek Wisata Bumi Perkemahan Palutungan Taman Nasional Gunung Ciremai Propinsi Jawa Barat. Prosiding Seminar Nasional Pengelolaan Sumberdaya Alam dan Lingkungan 2013, p 232-240. ISBN: 978-60217001-1-2. (online: diakses 10 September 2017, http://eprints.undip.ac.id/40669/1/035Silvia_Lucyanti.pdf).

Muta'ali. L. 2012. Daya Dukung Lingkungan Untuk Perencanaan Pengembangan Wilayah Yogyakarta. Yogyakarta: BPFG UGM.

Soemarwoto, O. 2008. Ekologi, Lingkungan Hidup dan Pembangunan Edisi ke-10. Jakarta: Djambatan. 